Images in...

\title{
Photosensitivity in systemic lupus erythematosus
}

\author{
François Alves, André Fragoso, Helena Brito, Idálio Mendonça \\ Department of Internal Medicine, Faro Hospital, Faro, Portugal
}

Correspondence to François Alves, jeanfrancoisalves@sapo.pt

\section{DESCRIPTION}

A 29-year-old woman with a history of antiphospholipid syndrome and systemic lupus erythematosus (SLE) with central nervous system involvement in remission for 2 years, presented with an erythematous cutaneous reaction after unprotected exposure to sunlight involving the face, neck, chest and shoulders (figure 1). The variable intensity of the eruption was related to the degree of skin exposure to ultraviolet (UV) radiation and the protective effect of the patient's clothing is visible (figure 2). Despite treatment, the cutaneous reaction worsened, extending to the hands and feet, with fever and cough. The diagnostic exams revealed only pancytopenia. Resolution of symptoms was achieved with the administration of corticotherapy and leucocyte growth factors.
Exposure to UV radiation can induce or exacerbate cutaneous and extracutaneous manifestations in SLE patients. ${ }^{1}$ This case highlights the importance of counselling such patients regarding avoidance of prolonged sun exposure and wearing protective clothing and sunscreen. ${ }^{2}$

Competing interests None.

Patient consent Obtained.

\section{REFERENCES}

1. Bens G. Photosensitivity in lupus erythematosus. Rev Med Interne 2009;30:857-65

2. Kuhn A, Ruland V, Bonsmann G. Photosensitivity, phototesting, and photoprotection in cutaneous lupus erythematosus. Lupus 2010;19:1036-46.

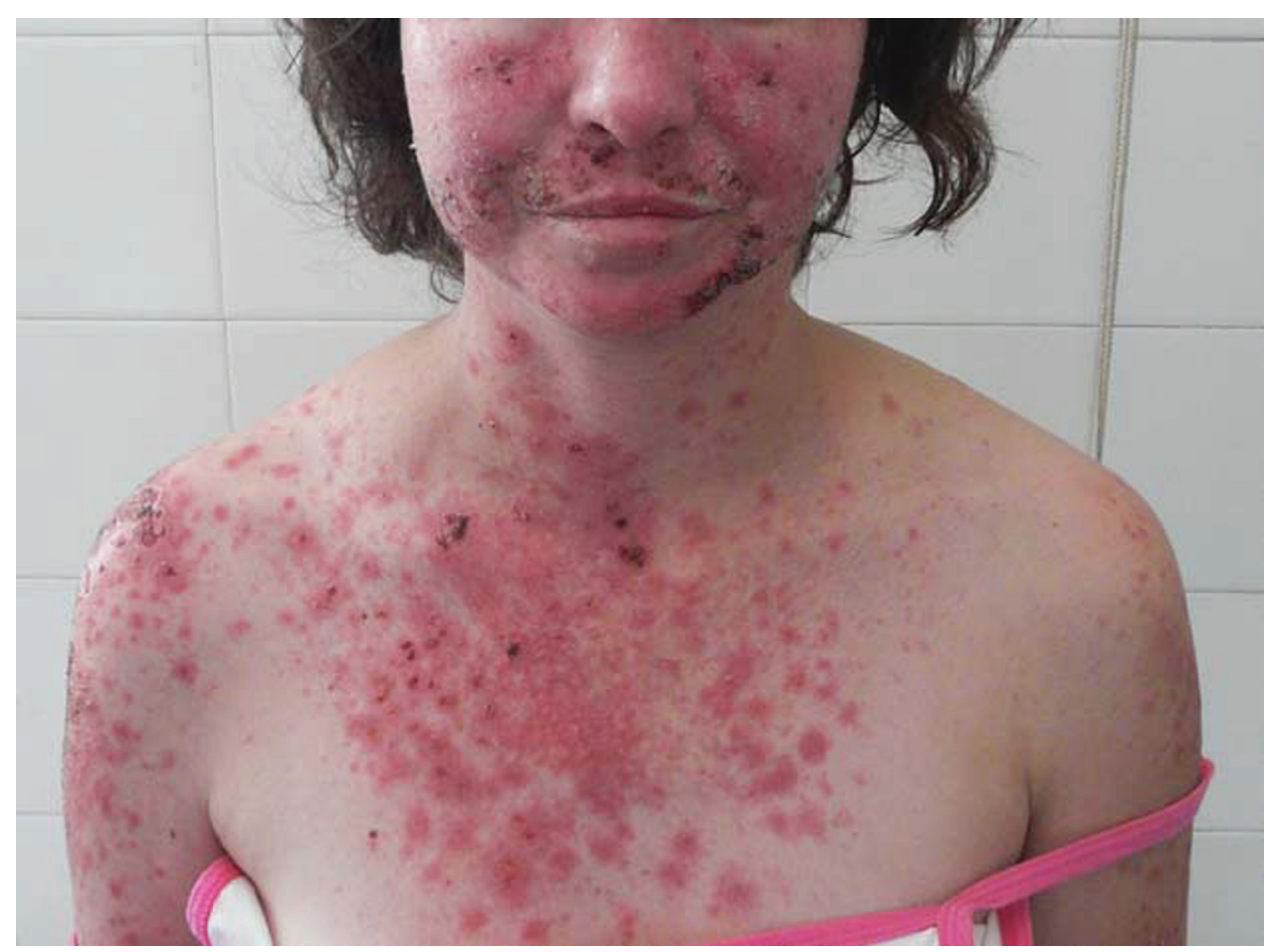

Figure 1 Erythematous cutaneous reaction after unprotected exposure to sunlight involving the face, neck, chest and shoulders in a patient with systemic lupus erythematosus. 


\section{BMJ Case Reports}

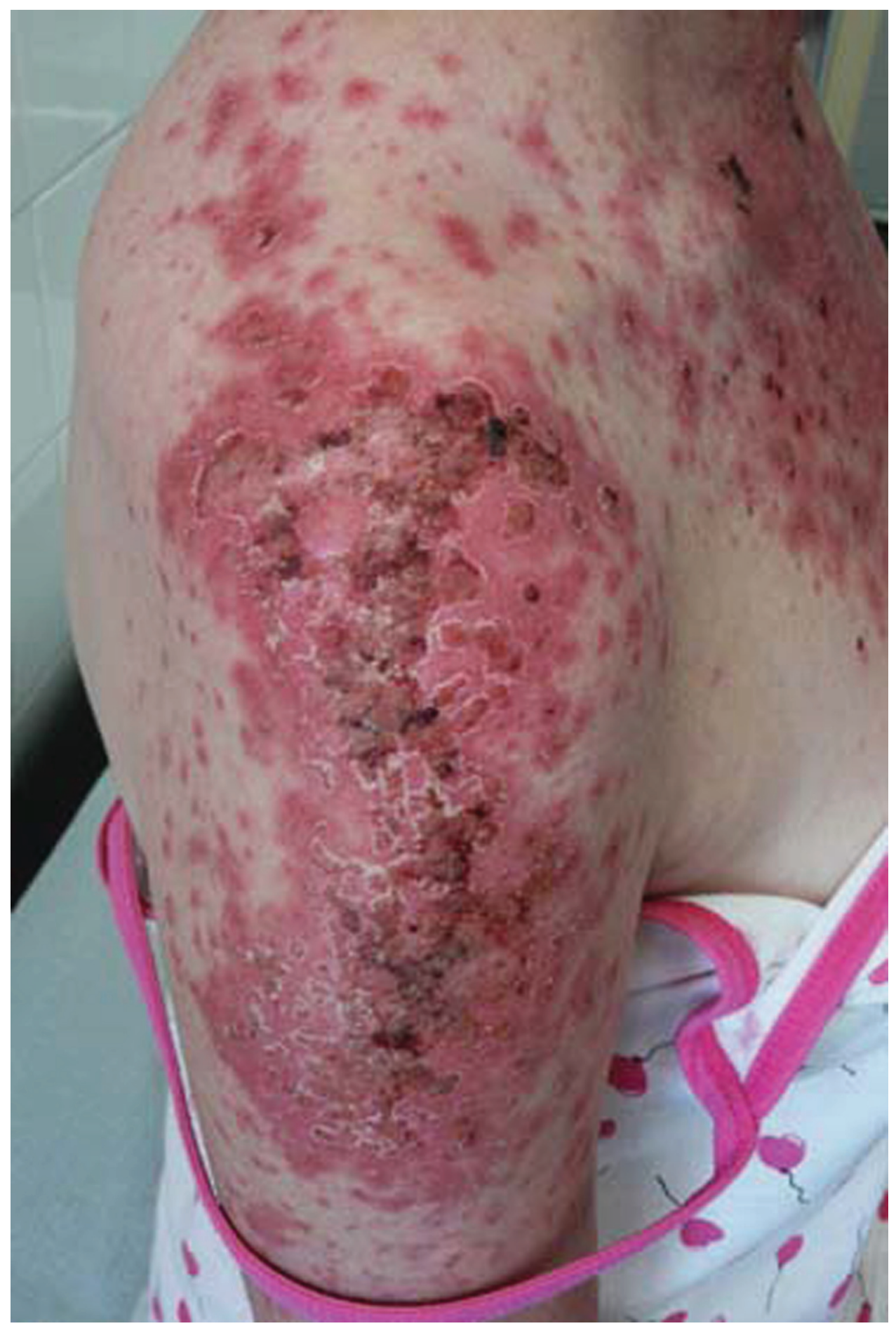

Figure 2 The variability of the eruption is related to the protective effect of the patient's clothing. 


\section{BMJ Case Reports}

This pdf has been created automatically from the final edited text and images.

Copyright 2011 BMJ Publishing Group. All rights reserved. For permission to reuse any of this content visit http://group.bmj.com/group/rights-licensing/permissions.

BMJ Case Report Fellows may re-use this article for personal use and teaching without any further permission.

Please cite this article as follows (you will need to access the article online to obtain the date of publication).

Alves F, Fragoso A, Brito H, Mendonça I. Photosensitivity in systemic lupus erythematosus. BMJ Case Reports 2011;10.1136/bcr.12.2010.3637, date of publication

Become a Fellow of BMJ Case Reports today and you can:

- Submit as many cases as you like

- Enjoy fast sympathetic peer review and rapid publication of accepted articles

- Access all the published articles

Re-use any of the published material for personal use and teaching without further permission

For information on Institutional Fellowships contact consortiasales@bmjgroup.com

Visit casereports.bmj.com for more articles like this and to become a Fellow 